\title{
Peran Orangtua Dalam Pendidikan Seksual Anak Usia Dini
}

\author{
Isabella Hasiana \\ ${ }^{1}$ Fakultas Pedagogik dan Psikologi, \\ Universitas PGRI Adi Buana Surabaya \\ email: isabella@unipasby.ac.id
}

\begin{abstract}
Abstrak
Orangtua memiliki peran di dalam memberikan edukasi kepada anak terkait dengan pendidikan seks. Pendidikan seks perlu diberikan sejak usia dini, karena mengingat semakin meningkat jumlah kasus kekerasan seksual kepada anak dan pelaku dari tindakan tersebut biasanya adalah orang yang sudah dikenal oleh korban. Tujuan dari penelitian ini untuk mendeskripsikan peranan orangtua didalam memberikan pendidikan seksual kepada anak usia dini. Penelitian dengan pendekatan kualitatif menggunakan desain studi kasus. Sumber informasi adalah keluarga yang memiliki anak dengan rentang usia 5-6 tahun. Tehnik analisa data dalam penelitian ini menggunakan analisa data Miles and Huberman. Hasil penelitian memberikan gambaran bahwa pada dasarnya orangtua sudah melakukan edukasi kepada anak dengan gaya bahasa sederhana yang mudah dipahami anak. Meskipun membicarakan seksual kepada anak masih dianggap tabu namun secara tidak disadari pendidikan seks sudah dilakukan oleh mereka. Sebagai contoh mengajarkan kepada anak untuk tidak menggunakan baju terbuka saat berada di luar rumah, tidak menggunakan perhiasan yang mencolok, dan lain sebagainya. Kesimpulan dari penelitian ini ialah orangtua semakin menyadari bahwa untuk mencegah terjadinya tindakan kekerasan seksual pada anak maka perlu dilakukan edukasi sejak dini kepada mereka.
\end{abstract}

Kata Kunci : orangtua, pendidikan seks, anak usia dini

\section{Abstract}

Parents have a role in providing education to children related to sex education. Sex education needs to be given from an early age, because considering the increasing number of cases of sexual violence experienced by children and the perpetrators of these acts are usually people who are already known by the victim. The purpose of this study is to describe the role of parents in providing sexual education to early childhood. This research is a qualitative research using a case study research design. Sources of information are families with early childhood, aged 5-6 years. Data analysis techniques in this study used data analysis by Miles and Huberman. The results of the study illustrate that basically parents have educated their children with a simple language style that is easy for children to understand. Although discussing sex with children is still considered taboo, they are not aware that sex education has been carried out by them. For example, teaching children not to wear open clothes when outside the house, not to use flashy jewelry, and so on. The conclusion of this study is that parents are increasingly aware that in order to prevent acts of sexual violence against children, it is necessary to educate them from an early age..

Keywords: parents, sex education, early childhood 
WAHANA

Volume 72, Nomor 2, Desember 2020

\section{PENDAhULUAN}

Berdasarkan informasi yang didapatkan dari Lembaga Perlindungan Saksi dan Korban (LPSK) bahwa jumlah pemohon terkait tentang perlindungan kekerasan seksual pada anak semakin meningkat. Jumlah kasusnya melebihi kasus tindakan kriminal yang lain. Selain itu LPSK juga memberikan catatan bahwa peningkatan kasus kekerasan seksual pada anak terus bertambah setiap tahunnya. Seperti pada diagram berikut ini ini.

\section{Gambar 1 Diagram Kekerasan Seksual Pada Anak}

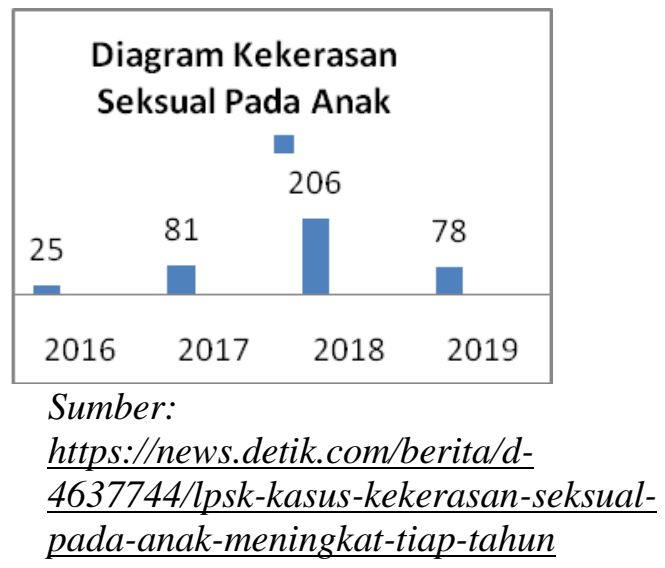

Kekerasan seksual yang dialami oleh anak menurut ECPAT (End Child Prostitution in Asia Tourism) Internasional secara umum terjadi karena adanya antara seorang anak dengan orang dewasa, dengan saudara kandung dan anak dijadikan sebagai objek pemuas nafsu seksual dari si pelaku tersebut (Zahira, Nurwati, Krisnani, 2019).

Dari tahun ke tahun kasus ini semakin meningkat dan hal ini menunjukkan bahwa dunia anak semakin tidak aman bahkan di dalam keluarga sendiri. Oleh sebab itu, diperlukan peran orangtua dalam memberikan informasi maupun perlindungan kepada anak agar terhindar dari kekerasan seksual.

Penelitian ini memiliki tujuan, yaitu untuk memperoleh gambaran tentang peranan orang tua dalam pencegahan kekerasan seksual bagi anak. Manfaat dan kontribusi dalam penelitian ini ialah agar anak lebih waspada terhadap tindakan kekerasan seksual yang akan dilakukan oleh orang lain.

Bagi pasangan suami dan istri tentu akan mengharapkan kehadiran seorang anak di dalam keluarga mereka. Orangtua juga memiliki harapan yang besar terhadap anak mereka. Namun seringkali harapan orangtua tidak berjalan dengan baik. Ada orangtua yang benarbenar mendidik dan meluangkan waktu untuk anaknya, namun ada juga orangtua yang memposisikan anak dan keluarga hanya sebagai pelengkap kehidupan saja. Orangtua seperti ini hanya menjadikan pekerjaannya sebagai prioritas utama dan menomor duakan keluarga.

Keluarga sebagai landasan yang utama dan pertama bagi anak. Di dalam keluarga pembelajaran tentang pendidikan seks menjadi suatu hal yang mendasar untuk diajarkan kepada anak sejak dini. Misalnya tentang perbedaan jenis kelamin, busana yang digunakan, cara duduk, dsb. Namun masih banyak orangtua yang menganggap bahwa hal tersebut bukan suatu hal yang penting dan bisa dibicarakan secara terbuka terutama dengan anak.

Menurut Mubarak (dalam Zahira, Nurwati, Krisnani, 2019) keluarga merupakan kumpulan dua bahkan lebih individu yang memiliki keterkaitan melalui hubungan pernikahan, hubungan darah, ataupun karena adanya adopsi dan setiap anggota keluarga yang ada saling berinteraksi satu dengan yang lain.

Agar tercipta sebuah hubungan harmonis di dalam keluarga, maka keluarga diharapkan dapat menjalankan fungsinya dengan baik. Adapun fungsi dalam keluarga menurut Friedman (dalam Zahira, Nurwati, Krisnani, 2019) adalah: a) Keluarga dengan fungsi afektif, yaitu untuk mengajarkan serta menyiapkan anggota keluarga untuk berhubungan dengan orang lain, b) Keluarga sebagai fungsi sosialisasi yaitu untuk menghasilkan interaksi sosial serta mempelajari peran individu di dalam lingkungan sosial, c) Keluarga sebagai fungsi reproduksi yaitu untuk melahirkan suatu generasi dan menjaga kelangsungan kehidupan keluarga, d) Keluarga sebagai fungsi ekonomi yaitu untuk memenuhi kebutuhan ekonomi keluarga dan meningkatkan penghasilan guna kesejahteraan keluarga, e) Keluarga berfungsi sebagai perawatan atau pemeliharaan kesehatan ialah untuk mempertahankan agar anggota keluarga memiliki keadaan kesehatan yang baik serta dapat meningkatkan produktifitas semakin tinggi.

Tiap anggota keluarga tidak hanya memiliki fungsi namun juga peran. Di dalam keluarga, ayah memiliki peran bukan hanya sebagai kepala keluarga tetapi juga pendidik dan pelindung, pencari nafkah serta memberikan rasa 
aman bagi anak dan istrinya. Selain itu di dalam anggota kelompok sosial dimana ia tinggal Ayah juga ikut berperan. Sosok Ibu juga memiliki peran dalam keluarga. Ibu berperan sebagai pengasuh dan pendidik anaknya serta pelindung saat ayah tidak berada di rumah. Tidak hanya itu saja, terkadang ibu juga sebagai pencari nafkah. Sedangkan anak didalam keluarga untuk dapat melaksanakan peran psikososial sesuai dengan tingkat perkembangan baik fisik, mental, sosial dan spiritual (Zahirah, Nurwati, Krisnani, 2019).

Namun, terkadang keluarga tidak menjalankan fungsi maupun perannya dengan baik sehingga dapat menyebabkan muncul permasalahan yang dialami oleh anak. Salah satunya adalah anak mengalami tindakan kekerasan seksual.

Kekerasan yang dilakukan kepada anak dapat dianggap sebagai suatu perilaku yang disengaja serta dapat menimbulkan dampak bagi korbannya baik secara fisik maupun emosional. Bentuk kekerasan yang dialami oleh anak yaitu kekerasan fisik, psikologi, sosial dan juga kekerasan secara seksual (Hurairah dalam Zahira, Nurwati, Krisnani, 2019).

Definisi dari kekerasan seksual yang dilakukan terhadap anak ialah setiap perbuatan yang cenderung memaksa untuk terjadinya hubungan intim namun dengan kondisi atau hal yang tidak wajar atau tidak disenangi. Sementara itu menurut Lynes (dalam Zahira, Nurwati, Krisnani, 2019) kekerasan seksual pada anak meliputi tindakan menyentuh atau mencium anggota tubuh anak, melakukan pemerkosaan anak, mempertontonkan benda atau film porno kepada anak, memperlihatkan alat kelamin pada anak dan sebagainya.

Pendapat lain tentang kekerasan seksual pada anak atau juga sering disebut dengan child sexual abuse adalah suatu bentuk penyimpangan perilaku yang dilakukan oleh orang dewasa atau orang yang lebih tua dan dilakukan kepada anakanak untuk memperoleh rangsangan seksual. Dampak yang akan dialami oleh anak pada saat mengalami kekerasan seksual, yaitu dampak secara psikologis, fisik dan sosial. Kekerasan seksual yang terjadi terhadap anak di bawah umur dapat terjadi karena pelaku kekerasan pernah sebagai status korban sehingga berpotensi akan menjadi pelaku. Selain itu, ada kecenderungan bahwa pelaku kekerasan pada anak merupakan orang yang dekat atau dikenal oleh korban. Misalnya, guru, tetangga, saudara bahkan teman juga memiliki potensi untuk menjadi pelaku.
Seperti yang telah disampaikan di atas bahwa pelaku kekerasan seksual lebih banyak dilakukan oleh orang yang dikenal korban. Sehingga pelaku kekerasan seksual dapat dikategorikan dalam dua hal yaitu (1) Familial Abuse (incest) ialah kekerasan seksual yang dilakukan oleh orang yang memiliki keterikatan hubungan darah dengan korban atau bisa diartikan bahwa pelaku merupakan bagian dari keluarga inti, (2) Extra Familial Abuse yaitu kekerasan seksual yang dilakukan oleh orang diluar lingkungan keluarga. Pelaku dari kategori ini ialah orang dewasa yang kenal dan dianggap dekat dengan keluarga inti dan telah memiliki hubungan relasi yang akrab antara pelaku dan korban. Namun hanya 40\% korban yang memiliki keberanian untuk melaporkan kekerasan yang dialaminya. Hal ini dikarenakan keluarga korban memiliki anggapan bahwa kejadian atau peristiwa kekerasan seksual tersebut merupakan hal yang tabu untuk dibicarakan secara umum dan menyangkut aib keluarga.

Extra Familial Abuse dilakukan oleh orang dewasa lainnya yang juga disebut dengan pedhopile dan yang menjadi korbannya adalah anak-anak. Arti Pedhopilia adalah pelaku kekerasan yang "menyukai anak-anak".

Berdasarkan situs sistem informasi online perlindungan perempuan dan anak (Simofa PPA) per 1 Januari sampai 31 Juli 2020 ada 3.296 anak perempuan dan 1.319 anak lakilaki yang menjadi korban kekerasan. Kasus kekerasan yang terjadi pada anak terdiri dari 1.111 merupakan kasus kekerasan fisik, 979 kekerasan dalam hal psikis, 2.556 ialah kasus kekerasan seksual, 68 merupakan eksploitasi, dan 73 kasus tindak pidana perdagangan orang, serta 346 kasus penelantaran

(https://nasional.kompas.com/read/2020/08/12/15 410871/kementerian-pppa-catat-ada-4116-kasuskekerasan-anak-dalam-7-bulan-

terakhir?page $=$ all) .

Contoh kasus yang terjadi pada tahun 2014 silam di Jakarta International School kepada anak TK yang mendapat perlakukan kekerasan seksual dimana pelakunya adalah guru dan karyawan sekolah tersebut. Kasus lain yang sampai menyebabkan korban meninggal dunia terjadi di Sukabumi, Jawa Barat. Seorang anak berusia 5 tahun dengan inisial NP menjadi korban pelecehan seksual dan pembunuhan yang dilakukan oleh ibu tirinya dan kedua kakak tirinya. Ironisnya sebelum dibunuh, NP diperkosa terlebih dahulu oleh kedua kakak tirinya dan perkosaan tersebut dilakukan di depan ibu tirinya 
(https://akurat.co/news/id-866041-read-5-kasuspelecehan-seksual-paling-bikin-geger-2019crosshijaber-hingga-pelemparan-sperma).

Menilik dari jumlah kasus diatas, dimana kasus kekerasan seksual terhadap anak semakin meningkat maka dengan kondisi seperti itu membuat orangtua menjadi cemas dan khawatir jika membiarkan anak untuk bermain di luar rumah ataupun saat anak ditinggal di rumah tanpa ibu maupun keluarga. Bahkan anggapan bahwa sekolah adalah suatu tempat yang membuat anak merasa aman sudah tidak sepenuhnya benar, karena tidak jarang pelaku kekerasan seksual pada anak juga dilakukan oleh guru, pegawai sekolah maupun teman sekolah.

Berdasarkan hasil observasi awal yang dilakukan oleh peneliti terhadap anak usia dini di lingkungan sekitar, menemukan bahwa ada 2-5 anak usia balita yang pernah menjadi korban kekerasan seksual. Seperti yang disampaikan oleh S, seorang anak perempuan berusia 5 tahun. Ia menceritakan tentang perlakuan pamannya yang senang sekali memegang bagian dadanya (Wawancara pada tanggal 20 Oktober 2019). S pun menceritakan perlakuan pamannya kepada ibu kandungnya. Namun oleh sang ibu, cerita $S$ ditanggapi dengan acuh. Kisah lain juga dialami oleh AF (anak laki-laki berusia 6 tahun) yang seringkali diminta untuk menunjukkan alat kelaminnya kepada tetangganya yang juga dengan jenis kelamin laki-laki.

Menyikapi kasus tersebut diatas, maka pentingnya pemberian pendidikan seks sejak usia dini. Ada beberapa faktor yang menjadi penyebab anak mengalami kekerasan seksual, yaitu:

\section{Faktor Internal}

Faktor penyebab ini merupakan faktor yang ada pada diri individu itu sendiri, terdiri dari:

a. Faktor biologis, manusia memiliki berbagai macam kebutuhan yang harus dipenuhi, dan kebutuhan itu meliputi kebutuhan akan makanan, seksual dan perlindungan dimana masing-masing kebutuhan tersebut dituntut untuk dipenuhi khususnya kebutuhan seksual.

b. Faktor Moral, faktor ini penting karena untuk merupakan filter terhadap munculnya perilaku yang menyimpang.

c. Faktor Kejiwaan, kondisi kejiwaan dari seseorang yang tidak normal dapat mendorong individu untuk melakukan kejahatan.

\section{Faktor Eksternal}

Faktor penyebab eksternal merupakan faktor yang terdapat dari luar sisi pelaku. a. Faktor media massa, media massa sebagai sarana informasi dalam kehidupan seksual. Artinya, banyak informasi yang dikabarkan oleh media massa dan terkadang didramatisir atau dilebih-lebihkan pemberitaannya. Hal ini dapat merangsang pembaca yang memiliki mental jahat untuk memperoleh informasi dalam melakukan kejahatan seksual terutama dengan korbannya adalah anak-anak.

b. Faktor ekonomi, faktor ekonomi dapat mempengaruhi seseorang untuk melakukan tindakan kejahatan. Hal ini dikarenakan seseorang yang dengan tingkat ekonomi rendah serta memiliki pekerjaan yang kurang dapat memenuhi kebutuhan sehari-hari menimbulkan kriminalitas termasuk dalam kejahatan seksual. Sebagai contoh, anak kecil yang dalam kesehariannya memakai perhiasan yang "mencolok" dapat menjadi salah satu faktor yang memicu terjadinya kekerasan seksual.

c. Faktor sosial budaya, semakin bertambahnya kasus kejahatan asusila atau pemerkosaan yang terkait dengan aspek sosial budaya. Hal ini diakibatkan dari semakin modernnya pemikiran dan perkembangan zaman sehingga budaya semakin berkembang dengan terbuka dan pergaulan juga semakin bebas (Zahirah, Nurwati, Krisnani, 2019).

Definisi pendidikan seks banyak sekali diungkapkan oleh para ahli. Namun sebenarnya pendidikan seks yang diberikan kepada anak sejak dini merupakan salah satu upaya untuk mengurangi atau mencegah dampak negatif yang tidak direncanakan, mencegah penyakit menular seksual, depresi maupun perasaan berdosa. Dikatakan juga bahwa pendidikan seks sangat penting untuk diberikan sejak usia dini karena menjadi penerang yang bertujuan untuk membimbing serta mengasuh anak laki maupun perempuan sejak usia dini khususnya tentang pergaulan antar jenis kelamin (Azis, 2015).

Selain itu pendidikan seks juga merupakan hal yang penting karena sebagai bentuk pengalaman yang benar kepada anak agar dapat membantu anak dalam melakukan penyesuaian diri terhadap kehidupannya di masa depan (Azis, 2015).

Bagi anak usia dini, tentu saja pendidikan seks diberikan sesuai dengan usia perkembangannya. Misalnya orangtua memperkenalkan kepada anak tentang organorgan seks miliknya secara singkat. Saat memandikan anak, orangtua dapat memberikan penjelasan tentang ini rambut, ini kepala, ini tangan, kaki, perut maupun alat kelamin. 
Orangtua juga memberikan informasi bahwa alat kelamin tidak boleh ditunjukkan ke orang lain dengan sembarangan, dan jika ada yang berusaha untuk menyentuhnya tanpa diketahui oleh orangtua maka anak harus berteriak sekeraskerasnya, lari ataupun melakukan usaha apapun untuk melindungi dirinya dan segera melapor kepada orang tua. Dengan demikian, anak akan dapat terlindungi dari maraknya kasus kekerasan seksual dan pelecehan seksual terhadap anak.

Terkait dengan hal tersebut diatas, orangtua dapat mengenalkan lagu "Sentuhan Boleh, Sentuhan Tidak Boleh" kepada anak sebagai salah satu cara pemberian pengajaran pendidikan seksual kepada anak. Melalui lagu ini, anak diajarkan untuk mengetahui bagian anggota tubuh yang boleh disentuh dan tidak oleh orang selain orangtua.

Lagu yang merupakan ciptaan Sri Seskya Situmorang dan dinyanyikan oleh Indri Ayu Lestari dapat dengan mudah dipahami dan dan dihafalkan oleh anak.

Berikut lirik lagunya.

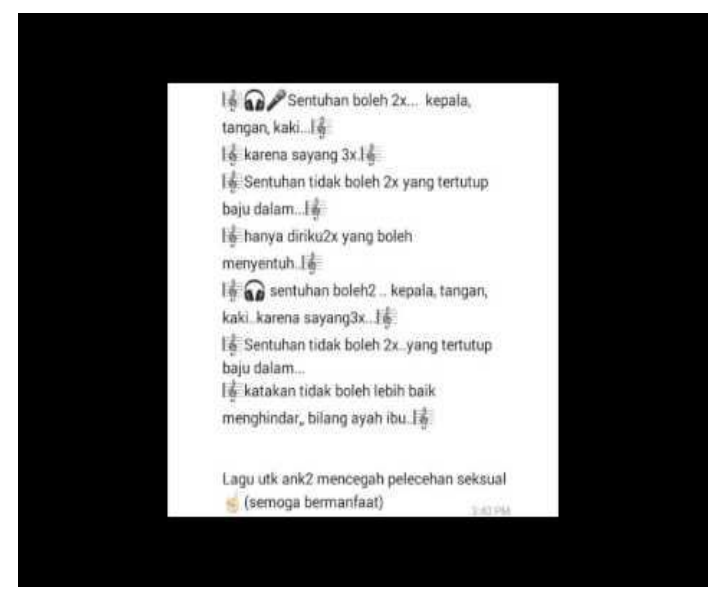

Sumber:

https://www.google.com/search?q=lagu+sentuhan $+b$ oleh\&safe $=$ strict \&rlz=1C1HLDY_idID726ID726\&so urce $=$ lnms \& tbm $=i s c h \& s a=X \& v e d=2 a h U K E w i \_w 6 S 3$ tpntAhVGb30KHSUiBv4Q_AUoAnoECAkQBA\&biw= 1366\&bih=695\#imgrc $=O S v w v t L M C t Q Q j M$

\section{METODE PENELITIAN}

Penelitian ini menggunakan pendekatan kualitatif. Pendekatan kualitatif adalah sebuah metode penelitian yang menggunakan latar alamiah, dengan maksud untuk menafsirkan fenomena yang terjadi dan dilakukan dengan menggunakan wawancara, pengamatan atau observasi, dan pemanfaatan dokumen (Moleong, 2015).
Penelitian ini menggunakan jenis penelitian kualitatif studi kasus (case studies) dan merupakan jenis penelitian kualitatif yang mendalam terhadap individu, kelompok, institusi, dan sebagainya dalam waktu tertentu. Sumber data yang juga sebagai subjek dalam penelitian ini adalah tiga keluarga yang memiliki anak usia dini pada rentang usia 5-6 tahun. Sedangkan teknik analisis data menggunakan model Miles dan Huberman.

\section{HASIL DAN PEMBAHASAN}

Berdasarkan wawancara dan observasi terkait dengan pendidikan seks yang dilakukan oleh orangtua, mak didapatkan hasil sebagai berikut:

1. Subyek 1 (AF)

\begin{tabular}{|l|l|}
\hline \multicolumn{2}{|c|}{ Riwayat Keluarga } \\
\hline Ayah & $\begin{array}{l}\text { Bekerja sebagai } \\
\text { karyawan Swasta }\end{array}$ \\
\hline Ibu & Wiraswasta \\
\hline Anak & $\begin{array}{l}\text { AF }(5 \text { tahun), } \\
\text { Perempuan }\end{array}$ \\
\hline $\begin{array}{l}\text { Orang yang tinggal } \\
\text { serumah }\end{array}$ & Tidak Ada \\
\hline
\end{tabular}

Orangtua AF terutama Ibunya, memiliki sebuah toko kecil yang ada di rumah sehingga lebih banyak waktu untuk mengurus AF. Kegiatan sehari-hari yang dilakukan selain mengurus toko, Ibu juga mengurus pekerjaan rumah dan membantu AF dalam mengerjakan pekerjaan sekolah anaknya. Selain itu, Ibu juga menyiapkan peralatan sekolah anaknya mulai dari pakaian hingga alat-alat tulis sekolah. Jika waktu luang mereka (ibu dan AF) menghabiskan waktu dengan pergi ke taman yang ada di dekat rumahnya. Bila ayahnya libur, maka mereka akan liburan ke luar kota. Hal ini muncul dalam wawancara pada tanggal 19 Oktober 2019 dan 26 Oktober 2019

Dalam kegiatan bermain, AF tidak diijinkan untuk bermain keluar rumah karena Ibunya tidak dapat mengawasi kegiatan AF saat bermain di luar rumah (Wawancara tanggal 26 Oktober 2019). Ibunya takut jika terjadi sesuatu yang tidak dinginkan kepada anaknya, seperti penculikan anak maupun pelecehan seksual. Untuk pendidikan terkait dengan seks, informasi yang diberikan oleh orangtua AF cenderung kurang terbuka karena orangtua beranggapan bahwa AF masih terlalu awam untuk mengenal pendidikan seksual (wawancara tanggal 26 
TN merasa minder dan pemalu. Hal ini

Oktober 2019). Alasan untuk tidak memberikan pendidikan seks secara mendalam dan terbuka, orangtua khawatir jika anaknya akan mengetahui hal-hal yang belum waktunya ia ketahui, misalnya berciuman dengan lawan jenis. Meskipun orangtua tidak memberikan pengarahan yang mendalam mengenai pendidikan seksual kepada $\mathrm{AF}$, namun Ibunya masih memberikan pendidikan dasar seksual seperti memberikan perlakuan kepada AF bila AF tidak memakai handuk seusai mandi. Ibu hanya mengatakan kepada AF agar lebih peka terhadap keadaan sekitar terutama dari orang yang tidak dikenalnya.

AF juga diberikan pengetahuan oleh ibunya untuk tidak mudah ikut ajakan orang dewasa yang tidak dikenalnya dengan "iming-iming" diberikan coklat, permen atau mainan. Selain itu karena AF anak perempuan, ibunya juga tidak memakaikan perhiasan yang berlebihan kepada $\mathrm{AF}$, untuk menghindari terjadinya tindakan kriminalitas.

\section{Subyek $2(\mathrm{TN})$}

\begin{tabular}{|l|l|}
\hline \multicolumn{3}{|c|}{ Riwayat Keluarga } \\
\hline Ayah & $\begin{array}{l}\text { Bekerja sebagai } \\
\text { karyawan Swasta }\end{array}$ \\
\hline Ibu & $\begin{array}{l}\text { Bekerja sebagai } \\
\text { karyawan Swasta }\end{array}$ \\
\hline Anak & $\begin{array}{l}\text { 1.AN (14 tahun), } \\
\end{array}$ \\
& $\begin{array}{l}\text { Perempuan } \\
\text { 2.TN (5 tahun), } \\
\text { Perempuan }\end{array}$ \\
\hline $\begin{array}{l}\text { Orang yang tinggal } \\
\text { serumah }\end{array}$ & Nenek \\
\hline
\end{tabular}

Dalam keseharian, TN lebih sering bermain sendiri karena orangtua sibuk bekerja. Saat bermain, TN diawasi oleh neneknya. Pada hari liburpun, TN lebih sering menghabiskan waktu dengan bermain sendiri. Hal ini dikarenakan, di lingkungan sekitarnya tidak banyak anak seusianya (wawancara tanggal 2 November 2019). Pendidikan yang diterapkan oleh orangtua dan neneknya cenderung keras / otoriter. Hal ini muncul dari wawancara yang dilakukan pada tanggal 02 November 2019, saat TN melakukan kesalahan yang disengaja ataupun tidak, orangtua bersikap keras dengan membentak ataupun menampar mulut TN. Hal ini membuat berdampak pada perilaku yang ditunjukkan oleh $\mathrm{TN}$, ia menjadi minder dan pemalu jika bertemu dengan orang lain terutama yang baru pertama kali dikenalnya. Selain itu, muncul perasaan khawatir jika TN melakukan sesuatu hal yang salah, sehingga dalam melakukan segala sesuatu, TN selalu bertanya dulu. Misalnya, "bolehkah saya makan dulu?, apa boleh bermain?, dll" (wawancara pada 23 Nopember 2019).

Terkait dengan pendidikan seks, orangtua memberikan arahan tentang ilmu seksual dasar mengenai rasa malu. Dalam artian, TN tidak diijinkan untuk pergi keluar rumah dengan pakaian yang terbuka. Selain itu, jika ada tamu, maka TN juga diharuskan untuk memakai pakaian (wawancara tanggal 23 Nopember 2019). Pendidikan seks yang ditekankan sebatas pada penampilan (pakaian), untuk hal yang lain tidak ditekankan oleh orangtua karena beranggapan hal tersebut tabu untuk dibicarakan.

3. Subyek 3 (UW)

\begin{tabular}{|l|l|}
\hline \multicolumn{2}{|c|}{ Riwayat Keluarga } \\
\hline Ayah & Wiraswasta \\
\hline Ibu & Wiraswasta \\
\hline Anak & $\begin{array}{l}\text { UW (6 tahun), Laki- } \\
\text { laki }\end{array}$ \\
\hline $\begin{array}{l}\text { Orang yang tinggal } \\
\text { serumah }\end{array}$ & Tidak Ada \\
\hline
\end{tabular}

Dikeluarga ini setiap anggota keluarga kurang sekali melakukan kegiatan bersama, karena kesibukan orangtua dalam bekerja. UW yang masih berusia 6 tahun sudah memiliki handphone sendiri, sehingga dalam keseharian dia jarang sekali bermain di luar rumah karena sibuk dengan handphonenya. Jika bermain handphone, UW bisa berjam-jam dan itu tidak ditegur oleh orangtuanya (wawancara dan observasi tanggal 23 November 2019).

Namun, meskipun orangtua sibuk bekerja di rumah, tetapi jika terkait dengan pendidikan, orangtua selalu memberikan perhatian. Orangtua beranggapan bahwa pendidikan adalah yang paling utama dibandingkan semuanya. Terkait dengan pendidikan seks, orangtua juga memberikan arahan kepada UW. Meski UW bermain handphone selama berjam-jam, namun orangtua memantau apa yang dilihat atau dimainkan oleh UW. Orangtua membatasi akses UW untuk melihat tayangan di youtube. Jadi UW hanya bermain game saja, dan jika ingin menonton youtube, orangtua secara khusus 
berlangganan youtube yang dikhususkan untuk anak-anak.

Orangtua UW memberikan pemahaman terkait dengan pendidikan seks. Orangtua beranggapan bahwa UW adalah laki-laki, maka ia harus mampu menjadi laki-laki yang bisa dibanggakan oleh orangtuanya dan tidak melakukan sesuatu hal yang dilarang oleh agama saat ia sudah dewasa nanti, misalnya pacaran sampai diluar batas wajar. (wawancara tanggal 28 November 2019). Selain itu, orangtua juga memberikan arahan kepada UW untuk hati-hati terhadap orang yang tidak dikenal. Karena rumah UW juga dijadikan toko, dan sering sekali berdatangan orang-orang yang tidak dikenal maka UW harus waspada jika ada orang yang memberikan permen, coklat atau mainan kepadanya tanpa ada pendampingan dari orangtuanya.

Berdasarkan temuan-temuan yang diperoleh di lapangan keluarga memiliki peran yang sangat penting dalam memberikan perlindungan atau meminimalisir agar tidak terjadinya kekerasan seksual yang dialami oleh anak. Kekerasan seksual yang terjadi pada anak di dalam keluarga dapat memberikan dampak negatif yang cukup panjang bagi anak. Hasil wawancara terhadap tiga keluarga yang menjadi subjek dalam penelitian ini, mereka sudah mampu dalam memberikan pendidikan seksual kepada anak dan bagaimana cara orangtua dalam memberikan pendidikan seksual tersebut. Secara khusus, keluarga sudah melakukan perannya dengan baik dalam mengarahkan, membina serta melindungi anak-anaknya. Meskipun sibuk bekerja, namun pendidikan seks menjadi perhatian khusus bagi mereka.

Orangtua sebagai pendidik tentang pendidikan seks berperan memberikan edukasi tersebut sejak anak berusia empat tahun. Hal ini dikarenakan pada usia tersebut anak mulai bersosialisasi secara intens dengan teman sebayanya, sudah menggunakan gawai (gadget).

Selain itu dalam menjelaskan kepada anak tentu menggunakan bahasa yang mudah dipahami anak, memberikan kasih sayang yang berkelanjutan, menjadi tauladan bagi anak dalam hal berpakaian, cara bergaul, dan orangtua diharapkan mampu menjadi sahabat bagi anak, menjadi pengawas juga bagi anak serta menjadi pendengar dan penasehat bagi anak. Seperti yang dilakukan oleh keluarga TN untuk tidak menggunakan baju yang terlalu terbuka saat berada di luar rumah. Hal-hal yang sederhana sebenranya bisa diajarkan kepada anak untuk menjaga dirinya dari perilaku yang berpotensi terjadinya tindakan kekerasan seksual.

Apabila pendidikan seksual tidak ditanamkan sejak usia dini kepada anak, maka akan menyebabkan anak memiliki pengetahuan tentang seksualitas dari sumber yang salah dan menerima informasi yang tidak benar. Akibat dari itu semua, maka akan terjadi tindakan yang tidak dapat dipertanggungjawabkan. Sebagai contoh, akan muncul banyaknya kekerasan seksual, mendorong anak untuk melakukan tindakan seksual terhadap anak lain, dan juga dapat berpengaruh terhadap pembentukan sikap, nilai dan jati diri anak.

Menurut Azis (2015), pendidikan seks merupakan sebuah pencerahan yang memiliki tujuan untuk membimbing serta mengasuh dengan baik laki-laki dan perempuan sejak dini dimulai dari anak-anak sampai saatnya mereka tumbuh dewasa terutama tentang bagaimana pergaulan antar jenis kelamin sehingga apa yang dilakukan oleh mereka terkait dengan kehidupan seksualnya dapat mendatangkan kebahagiaan dan kesejahteraan bagi umat manusia serta bisa dipertanggungjawabkan kepada Tuhan Yang Maha Esa.

Orangtua mempunyai tanggung jawab kepada anaknya untuk memberikan pendidikan, termasuk pendidikan seks. Dalam memberikan pendidikan seks, orang tua harus memperhatikan frekuensi pemberian, cara pemberian, dan materi pendidikan seks yang diberikan.

Dari hasil penelitian ini, terlihat bahwa tiga keluarga yang menjadi sumber informasi dalam penelitian menyadari bahwa mereka harus memberikan edukasi kepada anaknya tentang bagaimana berbusana, bagaimana bersikap dan bertingkah laku serta bagaimana mereka memperlakukan dirinya sendiri dengan baik. Tanpa disadari, orangtua-orangtua tersebut telah memberikan pendidikan seksual bagi anakanaknya.

Hal ini sejalan dengan penelitian Ariadi (2012) yang menjadikan frekuensi pemberian, cara pemberian, serta isi dari pendidikan seks yang diberikan kepada anak sebagai ukuran dalam pemberian pendidikan seks.

Pemberian pendidikan seks pada anak usia dini juga dapat dilakukan dengan memperkuat pendidikan agama, memperlakukan anak sesuai dengan kodratnya (sesuai dengan jenis kelamin anak, laki-laki atau perempuan), sering mengenalkan anatomi tubuh (nama-nama bagian tubuh) dan fungsinya secara sederhana pada anak, menjelaskan perbedaan anggota tubuh antara laki-laki dan perempuan pada anak, tidak 
WAHANA

Volume 72, Nomor 2, Desember 2020

merias wajah anak (berdandan) seperti dandanan/tampilan anak remaja/dewasa (misal memakaikan model pakaian dewasa, lipstik dan pensil alis), mengajarkan anak bagaimana berpakaian yang benar dan menutup aurat, sering menjelaskan bagaimana bergaul atau berteman yang benar dengan sesama jenis dan lawan jenis, dan tidak lari ketika anak bertanya tentang seputar seks.

\section{KESIMPULAN}

Dari penelitian ini, dapat disimpulkan bahwa orangtua telah memiliki pemahaman dan

\section{REFERENSI}

Azis. 2015. Pendidikan Keluarga: Konsep dan Strategi. Yogyakarta: Penerbit Gava Media

Desmita. 2015. Psikologi Perkembangan. Bandung: PT Remaja Rosdakarya.

Noormindhawati \& Enterprise. 2015. 8 Tahun yang Menakjubkan. Jakarta : PT Elex Media Komputindo.

Priyatna \& Oom. 2015. Stop It Now. Jakarta: PT. Gramedia.

Tridhonanto. Al, Beranda Agency.2014. Mengembangkan Pola Asuh Demokratis Jakarta: PT Elx Media Kompitindo

Moleong, Lexy J. 2015. Metodologi Penelitian Kualitatif. Bandung: PT Remaja Rosdakarya. pengetahuan tentang apakah itu pendidikan seks dan cara yang dilakukan dalam memberikan pendidikan seks kepada anak usia dini. Orangtua melakukan edukasi tersebut sesuai dengan tingkat pemahaman dari anak yang salah satunya dilakukan dengan nyanyian. Dengan pemberian pendidikan seks kepada anak sejak usia dini, maka akan mencegah terjadinya tindakan kekerasan seksual serta menjaga perilaku seksual anak di masa depannya.

Zahira, Nurwati, Krisnani, 2019. Dampak dan Penanganan Kekerasan Seksual Anak di Keluarga. Prosiding Penelitian dan Pengabdian Kepada Masyarakat. Volume 6 Nomor 1 Hal 10-20

Aziz, S. (2015). Penddikan Seks Anak Berkebutuhan Khusus. Yogyakarta : GAVA MEDIA.

Ariadi, A.D. (2012). Faktor-Faktor Yang Mempengaruhi Pemberian Pendidikan Seks Dari Orang Tua Terhadap Remaja Desa Pulau Kecematan Kelua Kabupaten Tabalong Provinsi Kalimantan Selatan. Skripsi, Universitas Muhammadiyah Banjarmasin. 